\title{
Antiviral Levans from Bacillus spp. Isolated from Honey
}

\author{
Mona A. Esawy, Eman F. Ahmed, Wafaa A. Helmy, \\ Nahla M. Mansour, Waled M. El-Senousy and Mounir M. El-Safty
}

Additional information is available at the end of the chapter

http://dx.doi.org/10.5772/52483

\section{Introduction}

In recent years, significant progress has been made in discovering and developing new bacterial polysaccharides that possess novel and highly functional properties (Baird et al 1983). Although their ubiquitous role in biological processes and their versatility as biocompatible, environmentally friendly materials are beyond doubt, polysaccharides are still considered to be the "sleeping giant" of biotechnology.

Honey contained a great variety of dominant spores and in consequence their dominant spores are expected to be new expolysaccarides sources which could be isolated. This expectation comes from the honey constituents which is mainly fructose (about $38.5 \%$ ) and glucose (about 31.0\%) (Crosby and Alfred 2004). Aerobic spore forming Bacillus were the most frequently encountered microbes on the external surface, crop and intestine of the honey bees and consequently honey (Root, 1993, Esawy et al., 2011).

Most of the researches in the honey field focused on its antimicrobial, antioxidant and anticancer activities, also the identification of the dormant endospore inside it (Sabate, et al., 2009). None till now paid attention to the enzymatic products of these dormant endospores (Esawy et al., 2011). Osmophilic microorganisms survive environmental extremes of desiccation, pressure and acidity, it is expected that their biopolymers will also have some unique properties to adapt to such extreme conditions. This investigation concerned the question of whether honey collect bacteria that are good producers of levansucrase and levan yield. Recently, screening of 16 bacterial honey isolates for levansucrase production showed that all the tested isolates were levansucrase producers despite variations in the degree of activity (data not published yet). Levansucrase, one of the fructosyltransferases or glycansucrases, is produced by various microorganisms 
(Iizuka et al.,1991; Hernandez, et al 1995; Kojima et al.,1993; Ben Ammar et al., 2002, Esawy et al., 2008). Bacterial levansucrases catalyze at least three different reactions: hydrolysis of sucrose, polymerization of fructose derived from sucrose and hydrolysis of levan. It is reported that levansucrase activity is involved in a variety of processes including survival of bacteria in soil (B. subtilis), phytopathogenesis (Erwinia and Pseudomonas species) and symbiosis (Paenibacillus polymyxa) of plant interactive bacteria (Hettwer et al.,1995). Bacillus subtilis, known as the hay bacillus or grass bacillus, is a Gram-positive, catalase positive bacterium commonly found in soil (Madigan \& Martinko, 2005). Recently, Esawy et al 2011, Esawy a et al 2012 and Esawy ${ }^{\mathrm{b}}$ et al 2012 reported in novel Bacillus subtilis honey isolates as new sources of very important enzymes such as levansucrase, dextranase and.lipase.

Levan is one of two main types of fructans, which are natural homopolymers of fructose (Arvidson et al 2006). It is a naturally occurring polymer of $\beta$-D-fructofuranose with $\beta$ $(2 \rightarrow 6)$ linkages between repeating five-member fructofuranosyl rings and branching at C1 (Arvidson et al 2006, Barone and Medynets., 2007). Levans produced by different organisms differ in their molecular weight and degree of branching. Levans from plants generally have molecular weights about 2000 - 33.000Da (Rhee et al., 2002). The molecular weight of levan, and the fraction of residues incorporated in side chains, depends on both the source and the growth conditions, with plant levan and microbially-produced levan having very different characteristics (Arvidson et al 2006; Kasapis, and Morris 1994; Kasapis et al., 1994; Newbrun 1971; Stivala, and Bahary 1978; Huber et al., 1994). Recently it was reported in the B. subtilis NRC1aza levansucrase, the unique feature of this isolate its ability to produce two types of levan with different molecular weights (El Fattah et al, 2012). Bacterial levans are much larger than those produced by plants, with multiple branches and molecular weights (2-100 million Da) (Pontis and Del Campillo 1985 ; Keith et al., 1991). Levan is non-gelling, non-swelling in water, (Kasapis et al., 1994; Stivala, and Bahary 1978; Huber et al., 1994) and an unusual polysaccharide due to its relatively low intrinsic viscosity compared to other molecules of similarly high molecular weights. Levan can be used as food or a feed additive with prebiotic and hypocholesterolemic effects (Sanders, et al., 2003). Subsequently, there are a variety of potential industrial applications for levan such as a surfactant for household use due to its excellent surfaceactive properties, a glycol/levan aqueous two-phase system for the partitioning of proteins, etc. In addition, in vitro anti-tumor activity of levan produced from Microbacterium laevaniformans, Rahnella aquatilis and Zymomonas mobilis, has been shown against eight different tumor cell lines (Urdaci, et al 2004; Yoo,et al 2004; Yoon et al.,2004; Liu et al., 2012; El Fattah et al, 2012). Recently, Liu et al., (2012) and El Fattah et al, 2012 reported in the antioxidant activity of native levan and their derivatives. Dahech et al., (2011) reported that polysaccharide levan is efficient in inhibiting hyperglycemia and oxidative stress induced by diabetes and suggests that levan supplemented to diet may be helpful in preventing diabetic complications in adult rats. The market for levan will gradually increase in the various fields (Kang et al., 2009). 


\section{Experimental}

\subsection{Sources of honey and microorganisms}

Three different honey samples were purchased; local honey bee collecting nectar from clover flower; Kashmiry honey, honey bee collecting nectar from desert flower (Saudi Arabian); and Gably honey, a honey bee collecting nectar from desert flower (Libya).

\subsection{Isolation of bacterial strains from honey samples}

One hundred micro liters of honey samples was spread on nutrient agar plates $(\mathrm{g} / \mathrm{L})$ : beef ext., 1.0; yeast ext., 2.0; peptone, 5.0 and agar, 25.0. After drying for $20 \mathrm{~min}$ in a laminar flow hood, the plates were incubated at $50{ }^{\circ} \mathrm{C}$ to avoid the growth of any pathogenic spores for $24 \mathrm{~h}$ or until the colonies size was sufficient (approximately larger than $3-5 \mathrm{~mm}$ in diameter). The bacterial isolates were streaked onto agar plates and preserved at $4{ }^{\circ} \mathrm{C}$. The purity of the isolates was assessed by colony morphology and microscopy.

\subsection{Chromosomal DNA and plasmid extraction}

Chromosomal DNA was prepared from overnight culture in LB,using AxyGEN Biosciences DNA extraction kit, according to manufacturer's instructions. Plasmid extraction was performed using Wizard mini prep. extraction kit (Promega) according to manufacturer's instructions with slight modification, where $50 \mathrm{~L}$ of lysozyme $(200 \mathrm{mg} / \mathrm{mL})$ were added to the resuspended buffer and incubated at $37^{\circ} \mathrm{C}$ for $1 \mathrm{~h}$ then the protocol was carried on as described in the kit (O'Sullivan \& Klaenhammer, 1993; Sambrook, et al., 1989).

\subsection{PCR amplification for molecular identification}

To amplify the 16S rRNA gene, a primer pair hybridizing to two conserved regions in $16 \mathrm{~S}$ rRNA genes from Bacillus spp. was used: (bac-F and bac-R) (Ash et al., 1991; Kwon et al., 2009). For the amplification of the 16-23S intergenic region, a primer pair was used: L516SF and L523SR. While for recA gene, a primer pair corresponding to conserved regions in recA genes from Bacillus $s p$. was used: recA-F and recA-R. Speciesspecific primer set for B. subtilis corresponding for ytcP gene was used: ytcP-F and ytcP-R. All polymerase chain reaction amplifications were performed with the Taq DNA polymerase kit (Promega). Reaction mixtures consisted of $20 \mathrm{~mm}$ Tris- $\mathrm{HCl}$ (pH 8.4), $50 \mathrm{~mm} \mathrm{KCl}, 3 \mathrm{~mm}$ $\mathrm{MgCl}_{2}, 50 \mathrm{~mm}$ of each of the four deoxynucleoside triphosphates (dNTP), $1 \mathrm{U}$ Taq polymerase, 5 pmol of each primer and $1 \mathrm{~L}$ of template DNA in a final volume of $50 \mathrm{~L}$. Samples were amplified in a GeneAmp polymerase chain reaction system 2700 (Applied Biosystems) programmed as follows: initial denaturation of DNA for $5 \mathrm{~min}$ at $94{ }^{\circ} \mathrm{C}, 30$ cycles of $30 \mathrm{~s}$ at $94{ }^{\circ} \mathrm{C}, 30 \mathrm{~s}$ at $50{ }^{\circ} \mathrm{C}$ and $30 \mathrm{~s}$ at $72{ }^{\circ} \mathrm{C}$. Polymerase chain reaction products were quantified by electrophoresis on a $1 \%(\mathrm{w} / \mathrm{v})$ agarose gel containing ethidium bromide. Polymerase chain reaction products obtained from the selected isolates were purified, using QIA quick polymerase chain reaction purification KIT (Qiagen) and then sequenced commercially by Sigma-Egypt. The sequencings were performed and manually 
aligned, using DNAMAN software (version 4.0). Sequence homologies were examined by comparing the obtained sequence with those in the NCBI database and the NEB cutter V 2.0 database. NEB cutter V 2.0 is an on-line DNA sequence tool used to find large, nonoverlapping, open-reading frames and works for all restriction enzymes. It provides a website, which allows users to check nucleotide sequences for restriction enzyme sites. The sequences were submitted and AluI enzyme was chosen for digestion. Finally gel photograph using $2 \%$ agarose was viewed (Ash et al., 1991).

\subsection{Bacterial strains and growth conditions}

Bacillus strains used in this work were cultivated in Luria-Bertani (LB) broth or agar at 37 ${ }^{\circ} \mathrm{C}$. Defined medium was used for cellular production of levansucrase (Yanase et al., 1992). It had the following composition $(\mathrm{g} / \mathrm{L})$ : yeast extract, 2.5 ; commercial sucrose, $80 ; \mathrm{MgSO}_{4}, 0.2$ and $\mathrm{K}_{2} \mathrm{HPO}_{4}$, 5.5. The medium was completed by the addition of $1 \mathrm{~L}$ distilled water and the $\mathrm{pH}$ was adjusted to 7.0 before autoclaving. The parameters included initial incubation temperature $\left(25-45^{\circ} \mathrm{C}\right)$; different concentrations of sucrose (80-160 g); incubation time (16$48 \mathrm{~h}) ;(50-150) \mathrm{rpm} ; \mathrm{pH}(5-9)$ and $\mathrm{NaCl}(1-4 \% \mathrm{w} / \mathrm{v})$ were studied. The sucrose was substituted with fructose, glucose, lactose $(80 \mathrm{~g} / \mathrm{L})$ and beet molasses (equivalent to $80 \mathrm{~g}$ sucrose) to study their effects on enzyme production.

\subsection{Cellular production}

Cultivation was carried out in $250 \mathrm{~mL}$ Erlenmeyer flasks. Each flask contained $50 \mathrm{~mL}$ production medium and was autoclaved for $15 \mathrm{~min}$. The flasks were then inoculated with $2.0 \mathrm{ml}$ inoculum and incubated for $24 \mathrm{~h}$ at $30^{\circ} \mathrm{C}$. The culture broth was then centrifuged in a cooling centrifuge (K70; Janektzki, Germany) at 10,397×g to separate the bacterial cells from the supernatant.

\subsection{Assay of levansucrase}

Levansucrase assay was performed according to the method of Yanase et al. (1992) with some modification. $0.5 \mathrm{ml}$ of culture filtrate was incubated with $1 \mathrm{ml} \mathrm{20 \%}$ (w/v) sucrose and $0.5 \mathrm{~mL} 0.1 \mathrm{M}$ acetate buffer at $\mathrm{pH} 5.2$ and incubated at $37^{\circ} \mathrm{C}$ for min. The decreasing amounts of sugars produced were measured by glucose oxidase kits. One unit of enzyme activity was defined as the amount of enzyme that produced decreasing sugars equivalent to 1 _mol of glucose/min.

\subsection{Separation of levan polymer}

The levan producing organisms were cultivated on a defined medium as described above. After growth, the culture was centrifuged to remove bacterial cells; the levan was precipitated with two volumes of absolute ethanol. The precipitate was collected and dried under vacuum. 


\subsection{Chromatography}

Paper chromatography was performed according to Block et al. (1995). Hydrolysate of products of levan were analyzed by either paper chromatography on whatman No. 1 . The mixtures at the end of incubation time were boiled for $3 \mathrm{~min}$ to stop the reaction. Chromatographic development was carried out with a solvent system of $n$ butanol:acetone:water (4:5:1) and detected by spraying with aniline hydrogen phthalate. The acid hydrolysate of the polysaccharide produced by the six isolates was analyzed using high-pressure liquid chromatography (HPLC). A $7.8 \mathrm{~mm} \times 300 \mathrm{~mm}$ PL-HI-PLEXPB column was linked to a differential refractometer. The column temperature was maintained at $80^{\circ} \mathrm{C}$. The aqueous mobile phase was delivered at a flow rate of $0.6 \mathrm{ml} / \mathrm{min}$.

\subsection{Determination of molecular weight}

Different concentrations of levan and oligosaccharide were prepared and the flow time of equal volume for each concentration at $30^{\circ} \mathrm{C}$ was determined in a U-shaped Ostwald viscometer. Flow time of the same volume of distilled water was also determined as control. Thus, specific viscosity/C (gsp) was estimated. A plot of levan and oligosaccharide concentration $(\mathrm{C})$ against intrinsic viscosity $(\mathrm{C})(\mathrm{gsp} / \mathrm{C})$ therefore yielded a straight line.

\subsection{Antivirus detection}

Two types of viruses were used, highly pathogenic avian influenza H5N1 virus Egyptian isolate, was used at titre of 106 EID50/mL (embryo infective dose per $\mathrm{mL}$ ) and adenovirus type 40 with different doses $20^{1} \times 10^{4}, 1 \times 10^{5}$, and $1 \times 10^{6}$ infectious particles/mL obtained from the Holding Company for Biological Products \& Vaccines (VACSERA).

\subsection{Specific pathogen free (SPF) eggs}

SPF embryonated chicken eggs were used at nine days old and inoculated via the allantoic sac route. SPF eggs (Brown et al., 2007) were obtained from Nile SPF Eggs, Koomoshiem, Fayoum, Egypt.

\subsection{Cytotoxicity test}

It was done according to Simoes et al., (1999) and Walum et al., (1990). Briefly, All samples (100 mg) were dissolved in 500 _L of water or ethanol. Samples A, E, M, and K were dissolved in ethanol while samples $C$ and $G$ were dissolved in water. Decontamination of samples was done by adding 12 _L of $100 x$ of antibiotic-antimycotic mixture to 500 _L of each sample. Then, bi-fold dilutions were done to $100 \_$L of original dissolved samples and 100 _L of each dilutions were inoculated in Hep-2 cell line (obtained from the Holding Company for Biological Products \& Vaccines VACSERA, Egypt) previously cultured in 96 multi well plates (Greiner-Bio one, Germany) to estimate the non toxic dose of the tested samples. Cytotoxicity assay was done using cell morphology evaluation by inverted light microscope and cell viability test applying trypan blue dye exclusion method. 


\subsection{Cell morphology evaluation by inverted light microscopy}

Hep-2 cell cultures $\left(2 \times 10^{5}\right.$ cells $\left./ \mathrm{mL}\right)$ were prepared in 96-well tissue culture plates (GreinerBio one, Germany). After $24 \mathrm{~h}$ incubation at $37^{\circ} \mathrm{C}$ in a humidified $5 \%(\mathrm{v} / \mathrm{v}) \mathrm{CO} 2$ atmosphere cell monolayers were confluent, the medium was removed from each well and replenished with 100 _L of bi-fold dilutions of different samples tested prepared in DMEM (GIBCO BRL). For cell controls 100 _L of DMEM without samples was added. All cultures were incubated at $37^{\circ} \mathrm{C}$ in a humidified $5 \%$ (v/v) CO2 atmosphere for $72 \mathrm{~h}$. Cell morphology was observed daily for microscopically detectable morphological alterations, such as loss of confluence, cell rounding and shrinking, and cytoplasm granulation and vacuolization. Morphological changes were scored (Simoes et al., 1999).

\subsection{Cell viability assay}

It was done by trypan blue dye exclusion method (Walum et al., 1990). Hep-2 cell cultures $\left(2 \times 10^{5}\right.$ cells $\left./ \mathrm{mL}\right)$ were grown in 12 -well tissue culture plates (Greiner-Bio one, Germany). After $24 \mathrm{~h}$ incubation, the same assay described above for tested samples cytotoxicity was followed by applying $100 \mathrm{~L}$ of tested samples dilutions (bifold dilutions) per well. After $72 \mathrm{~h}$ the medium was removed, cells were trypsinized and an equal volume of $0.4 \%(\mathrm{w} / \mathrm{v})$. Trypan blue dye aqueous solution was added to cell suspension. Viable cells were counted under the phase contrast microscope.

\subsection{Haemagglutinating activity assay}

This was applied for the allantoic fluids of the inoculated eggs and measured by micro technique of haemagglutination (HA) test (Takatsy, 1955).

\subsection{Evaluation for antiviral activity}

Three experiments were conducted.

\subsubsection{Experiment 1}

One hundred and five emberyonated chicken eggs (ECEs) were examined; equal volumes of HPAI H5N1 virus and original extracts were separately used at three levels:

Level 1: Equal volumes of HPAI H5N1 virus and the original undiluted samples were mixed and incubated at room temperature for $1 \mathrm{~h}$ then inoculated into the allantoic sac of five ECEs for each product sample at dose $0.2 \mathrm{~mL} / \mathrm{ECE}$.

Level 2: Equal volumes of HPAI H5N1 virus and the 1/5 dilution of each sample were mixed and preceded as level 1.

Level 3: Equal volumes of the virus and the 1/10 dilution of each sample were mixed and preceded as level 1. In addition, five ECEs were inoculated with the virus that mixed with equal volume of saline at a dose of $0.2 \mathrm{~mL} / \mathrm{ECE}$ of saline alone (negative control). The ECEs are inoculated at $37^{\circ} \mathrm{C}$ and candled every $2 \mathrm{~h}$ till all the positive control ECEs died. 


\subsubsection{Experiment 2}

One hundred and five SPF ECEs were used in this experiment; equal volumes of HPAI $\mathrm{H} 5 \mathrm{~N} 1$ virus and the original samples were mixed with equal volume of the original samples and inoculated directly into the allontoic sac of five ECEs for each product sample at a dose of $0.20 \mathrm{~mL} / \mathrm{ECE}$ for each product sample at a dose of $0.2 \mathrm{~mL} / \mathrm{ECE}$. Five ECEs were inoculated with equal volume of the HPAI H5N1 virus and saline at dose of $0.2 \mathrm{~mL} / \mathrm{ECE}$ (positive control). Another five ECEs were inoculated with $0.20 \mathrm{~mL} / \mathrm{ECE}$ of saline alone (negative control). All the ECEs were incubated at $37^{\circ} \mathrm{C}$ and controlled every $2 \mathrm{~h}$ till the ECEs of the positive control died

\subsubsection{Experiments 3}

One hundred and five SPF ECEs of nine days old were used in this experiment. $0.10 \mathrm{~mL}$ of the HPAI H5N1 virus was inoculated via the allontoic sac of each ECE into 100 ECEs and then the inoculated ECEs were incubated for $1 \mathrm{~h}$ at $37{ }^{\circ} \mathrm{C}$. The original samples were inoculated into five ECEs, which previously inoculated with the virus at a dose of $0.1 \mathrm{ml}$. Another five ECEs were inoculated with $0.2 \mathrm{ml} / \mathrm{ECE}$ of the mixed virus and saline. Other five ECEs were inoculated with $0.2 \mathrm{ml} / \mathrm{ECE}$ of saline alone. The ECEs were inoculated at 37 ${ }^{\circ} \mathrm{C}$ and candled every $2 \mathrm{~h}$ till ECEs of the positive control died.

\subsection{Antiviral effect of tested samples on adenovirus type 40}

Seventy five microliters of non toxic dilutions were mixed with $75 \mathrm{~L}$ of different doses $1 \times 10^{4}, 1 \times 10^{5}$, and $1 \times 10^{6}$ infectious viral particles/mL of adenovirus type 40 provided by American Type Culture Collection (ATCC). Then the mixture was incubated overnight at 4 ${ }^{\circ} \mathrm{C}$. Inoculation of $100 \mathrm{~L}$ of 10 fold dilutions of treated and untreated adenovirus was done into Hep-2 cell line in 12 multi well-plates. After $1 \mathrm{~h}$ incubation for adsorption at $37^{\circ} \mathrm{C}, 1 \mathrm{~mL}$ medium (DMEM) was added to each well. The cell line was observed daily for one week then, three times freezing and thawing for tested plates were done. Nested PCR was done for confirmation of adenovirus (presence/absence) in each well (Puig et al., 1994).

\section{Results}

\subsection{Molecular identification of the levansucrase producers strains}

\subsection{1. $16 S$ rRNA sequences and their analogical electrophoresis}

Six levansucrase producers' bacteria were isolated from different honey sources. The isolates resembled each other in cell morphology where cells were rod-shaped, Gram-positive, motile and spore-forming. Colonies were circular, creamy, and no pigment was formed. They were identified as Bacillus spp. based on morphological examination. The identification was confirmed by molecular biological analysis, using $16 \mathrm{~S}$ rRNA sequencing method. The results showed that the 6 isolates were identified as Bacillus spp. (99\%), or B. licheniformis (99\%), or B. amyloliquefaciens (99\%) ( Fig. 1). 


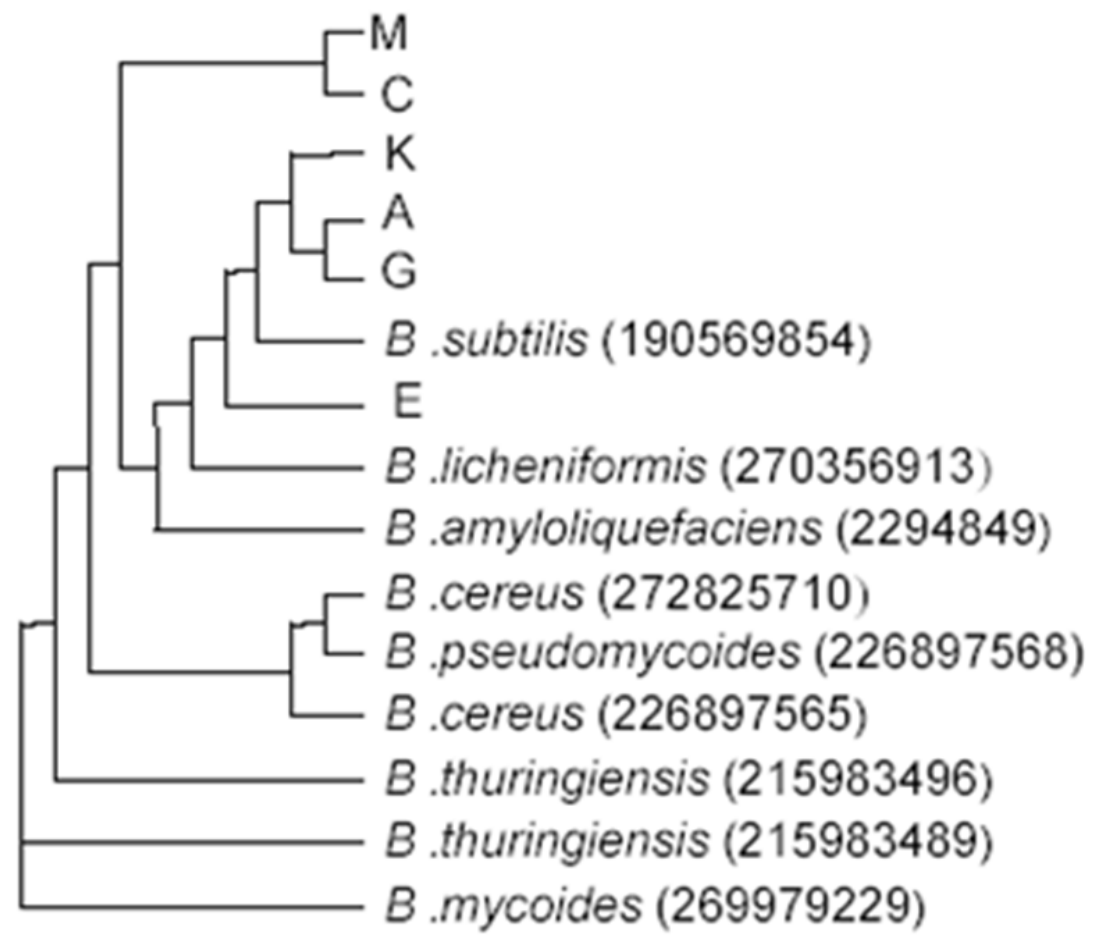

Figure 1. Phylogenetic neighbor-joining tree obtained by $16 \mathrm{~S}$ rRNA sequence analysis of the tested isolates and other Bacillus spp. present in the gene bank database (accession numbers in parentheses).

The DNA of the isolates was extracted as described in Section 2 and the $1.5 \mathrm{~kb} 16 \mathrm{~S}$ rRNA gene was amplified for each DNA by PCR using primers bac-F and bac-R. The PCR amplification, purification and sequencing were performed as described previously. The $1.5 \mathrm{~kb}$ obtained sequences were aligned and clustered with sequences from the NCBI database. 16S rRNA gene sequence analysis indicated that the six isolates $(K, M, A, C, E$, and $G$ ) were Bacillus spp. with $99 \%$ identity any of these three species B. subtilis, or B. licheniformis, or B. amyloliquefaciens and they clustered into a monophyletic line in a phylogenetic tree. To distinguish and clear identification of these strains on the species level the analogical electrophoresis, using NEB cutter was applied to identify the $16 \mathrm{~S}$ rRNA results, which have been sequenced, as the strains of the same species expected to have almost the same sites when digested with AluI. Fig. 2 showed that the isolates $M$ and $G$ have the same size fragments as B. subtilis gi 269313996 while the other isolates A, C, E; K showed different AluIfragments which differ to the AluI fragments generated from 16S rRNA sequence of B. subtilis, or B. licheniformis or B. amyloliquefaciens. It was clear that 16S rRNA gene alone could not distinguish these three closely related Bacillus species. 


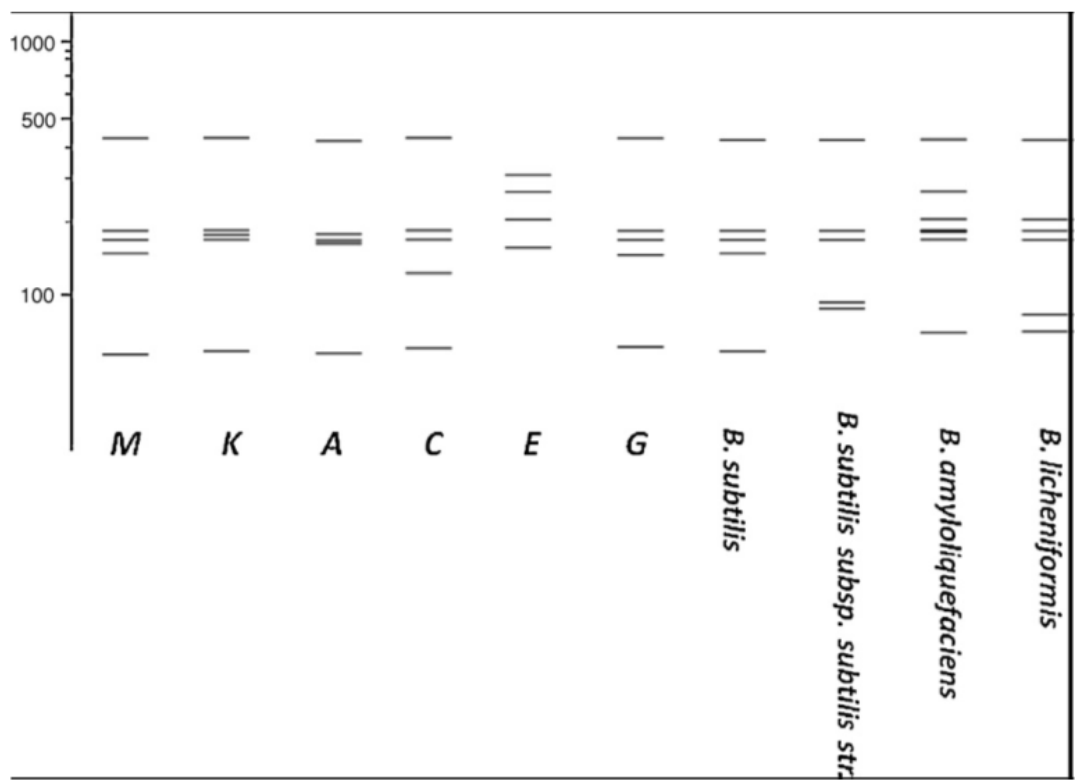

Figure 2. The analogical electrophoresis of Bacillus isolates compared to Bacillus strains (from the gene bank) by "AluI", using NEBcutter 2.0. The accession no. of the control Bacillus strains: B. subtilis gi |269313996।; B. subtilis subsp. subtilis str. AL009126.3; B. amyloliquefaciens gi I229484923।; and B. licheniformis gi|270356913|.

\subsection{Identification by $16-23 S$ intergenic region}

To distinguish between these three closely related strains the 16-23S intergenic region was amplified by primers L516SF $\times$ L523SR, and then the sequence was determined for the six isolates. The homology results for the 16-23S intergenic region showed that: $\mathrm{K}$ and $\mathrm{M}$ strains showed $100 \%$ similarity to B. subtilis but strains A, C, E, G could be either B. subtilis (99\%) or B. amyloliquefaciens (85\%) (Table. 1.).

\begin{tabular}{|l|l|l|l|}
\hline Target & $\begin{array}{l}\text { Primer } \\
\text { name }\end{array}$ & Oligonucleotide & Reference \\
\hline $\begin{array}{l}\text { 16-23S } \\
\text { intergenic } \\
\text { region }\end{array}$ & $\begin{array}{l}\text { L516SF } \\
\text { L523SR }\end{array}$ & $\begin{array}{l}5^{\prime} \text {-TCGCTAGTAATCGCGGATCGGC-3' } \\
\text { 5'-GCATATCGGTGTTAGTCCCGTCC-3' }\end{array}$ & $\begin{array}{l}\text { Yoon et al., } \\
2001\end{array}$ \\
\hline recA gene & $\begin{array}{l}\text { recA-F } \\
\text { recA-R }\end{array}$ & $\begin{array}{l}5^{\prime} \text {-TGAGTGATCGTCAGGCAGCCTTAG-3' } \\
5^{\prime} \text {-CYTBRGATAAGARTACCAWGMACCGC-3' }\end{array}$ & $\begin{array}{l}\text { Gun-Hee } \\
\text { Kwon et al., } \\
\text { (2009) }\end{array}$ \\
\hline $\begin{array}{l}\text { hypotheticl } \\
\text { gene }\end{array}$ & $\begin{array}{l}\text { ytcP-F } \\
\text { ytcP-R' }\end{array}$ & $\begin{array}{l}5^{\prime} \text {-GCTTACGGGTTATCCCGC-3' } \\
5^{\prime} \text { CCGACCCCATTTCAGACATATC-3' }\end{array}$ & $\begin{array}{l}\text { Gun-Hee } \\
\text { Kwon et al., } \\
(2009)\end{array}$ \\
\hline
\end{tabular}

Table 1. Primers used for gene amplification 


\subsection{Identification by recA sequence}

Hence the recA gene has been used as a molecular chronometer in addition to rRNA genes. The $1.2 \mathrm{~kb}$ band was gel isolated and subjected to sequencing results and showed that the four strains A, C, E, and G were B. subtilis rather than B. amyloliquefaciens. Still these results need more confirmation.

\subsection{Identification by specific-PCR for B. subtilis}

To solve this problem, identification using specific-PCR for B. subtilis was described. Based on ytcP gene encoding a hypothetical protein, a PCR primer pair ytcF and ytcR were designed for $B$. subtilis species for specific amplification purpose. Using this primer pair, a $0.46 \mathrm{~kb}$ fragment was amplified only from $B$. subtilis strains, whereas no similar band was detected from B. licheniformis or B. amyloliquefaciens strains. These primers were subjected to the six isolates and PCR resulted in the $0.46 \mathrm{~kb}$ band as shown in Fig. 3 and this confirmed that all isolates A, C, E, G, K, M surely belong to B. subtilis not $B$. amyloliquefaciens.

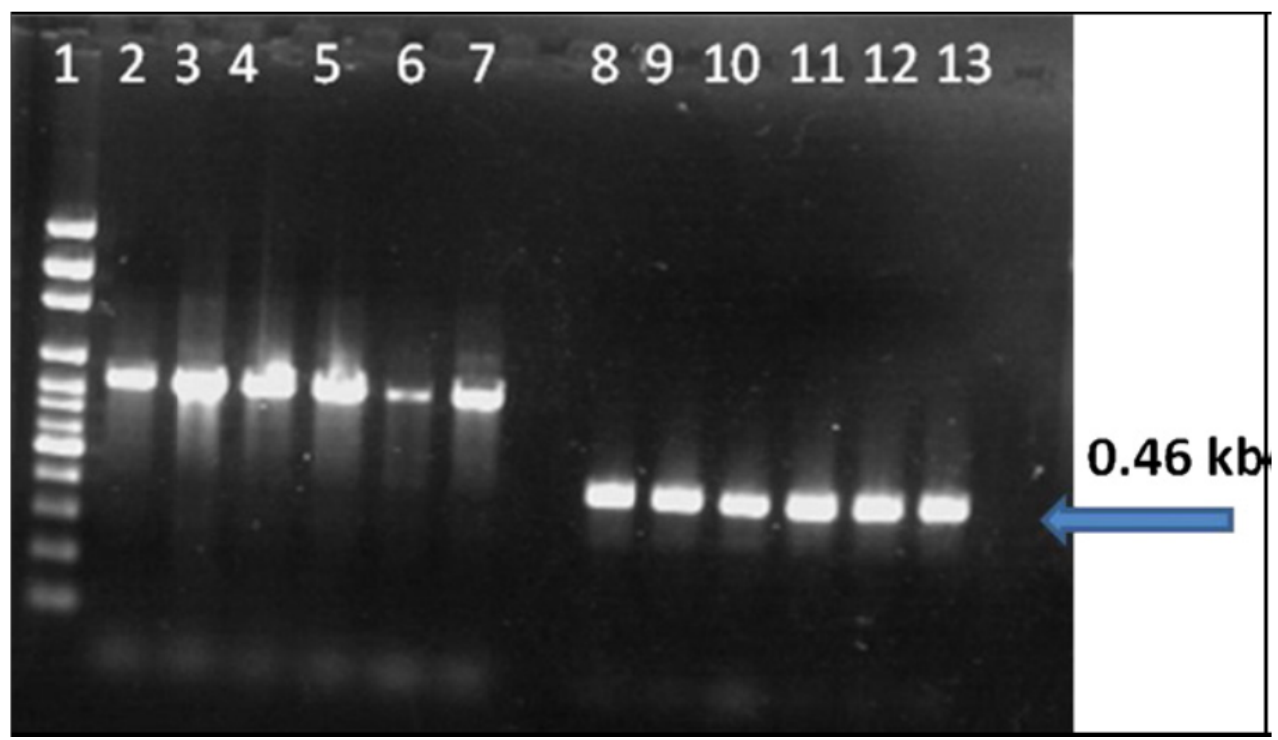

Figure 3. PCR using the chromosomal DNA of the 6 Bacillus isolates. Lane 1, 100 bp ladder; lane 2-7, using primers recR $\times$ recF; lane $8-13$, using $B$. subtilis specific primers ytcF $\times y t c R$.

\subsection{Levan and levansucrase production}

The six honey isolates were tested for production of levansucrase, the optimized conditions for the isolates ranged from 8 to $12 \%(\mathrm{w} / \mathrm{v})$ commercial sucrose, $37-40{ }^{\circ} \mathrm{C}, 24$ $28 \mathrm{~h}, 50-100 \mathrm{rpm}$ and $\mathrm{pH}$ 6-7.0 (data not shown). Among all the tested isolates, $\mathrm{M}$ and $\mathrm{K}$ isolates showed the highest levansucrase activities (62 and $59 \mathrm{U} / \mathrm{mL}$ ). The presence of 
$\mathrm{NaCl}(1-4 \%, w / v)$ showed great influence in enzyme activity, the enzyme production increased from 2 to 3 folds according to the strain (Fig. 4). Paper chromatography of the product hydrolysate revealed the presence of only fructose and tiny traces of glucose, pointing to the levan nature of the product. Furthermore, the acid hydrolysate of the polysaccharide produced by the isolates was exclusively fructose, as revealed by HPLC. Levan was harvested by precipitation from the culture broth by addition of ethanol. The yield and consistency of the product varied according to the isolate. The final products were a brownish-white gummy material, which could be freeze-dried or vacuum-dried. The highest amount of levan was produced on the medium containing commercial sucrose, followed by beet molasses (Fig. 5). While a small amount of microbial polysaccharide (alcohol precipitate) was also produced when the organism was grown on lactose and glucose, it was worthy to record that no polysaccharides were produced on fructose. The amounts of levan decreased $40-50 \%$ in the presence of $\mathrm{NaCl}$. Isolates $\mathrm{M}, \mathrm{K}$, A, C, E, and G produced 11, 16.25, 6.60, 1.81, 1.74, $6.6 \mathrm{~g} / \mathrm{L}$ levan, respectively under the optimized conditions. The levan products consisted of one fraction characterized by high and low molecular masses (40.938, 71.887, 43.487, 154.638, 77.753 and $14.200 \mathrm{kDa}$ for isolates K, M, A, C, E, and G, respectively) (Fig. 6).

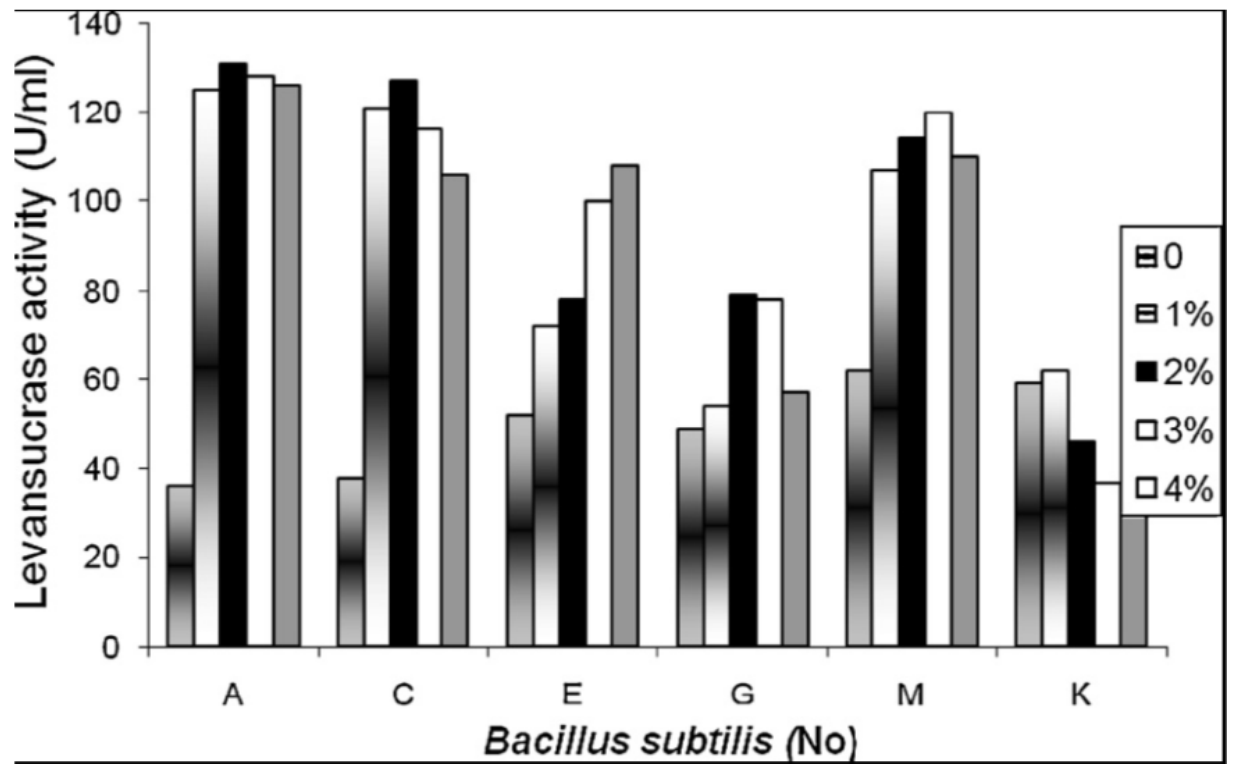

Figure 4. The effect of absence and presence of different concentrations of $\mathrm{NaCl}$ on levansucrase production from honey isolate. Note: $\mathrm{NaCl}$ conc (0-4\%) represented from left to right. 


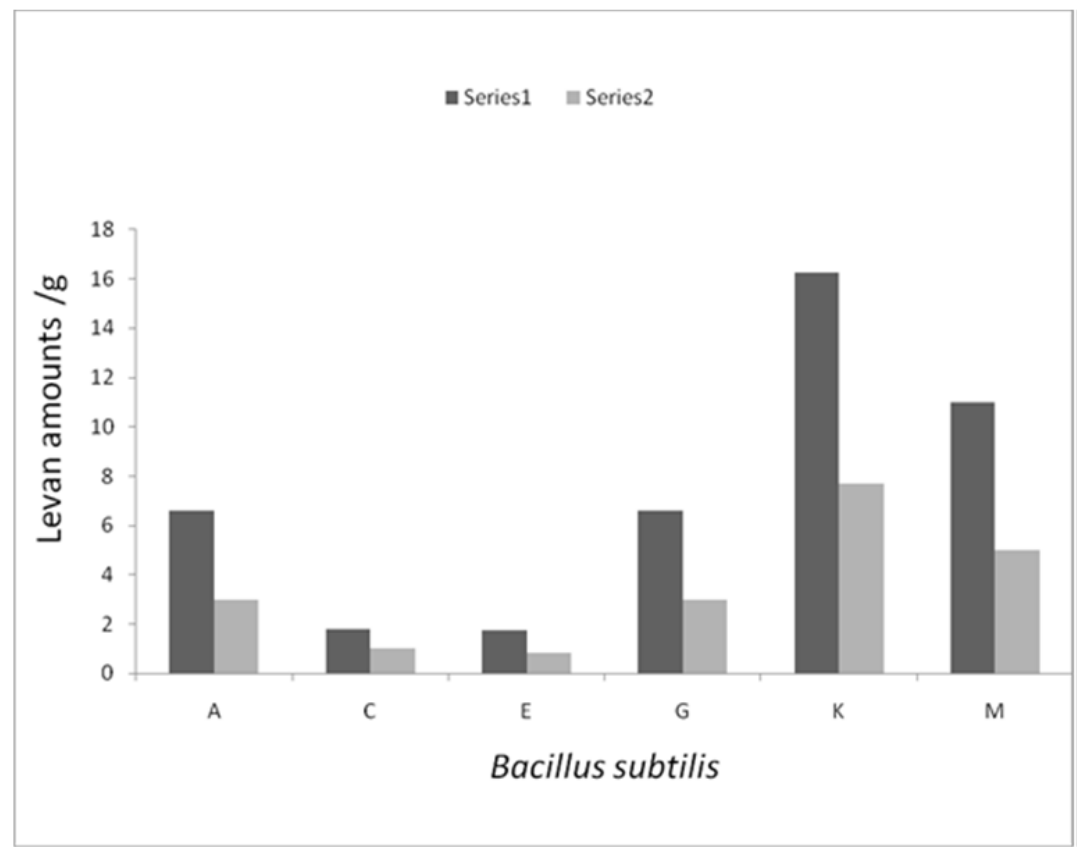

Figure 5. The difference between amounts of levan produced in sucrose medium (series 1) and in molasses medium (series 2)

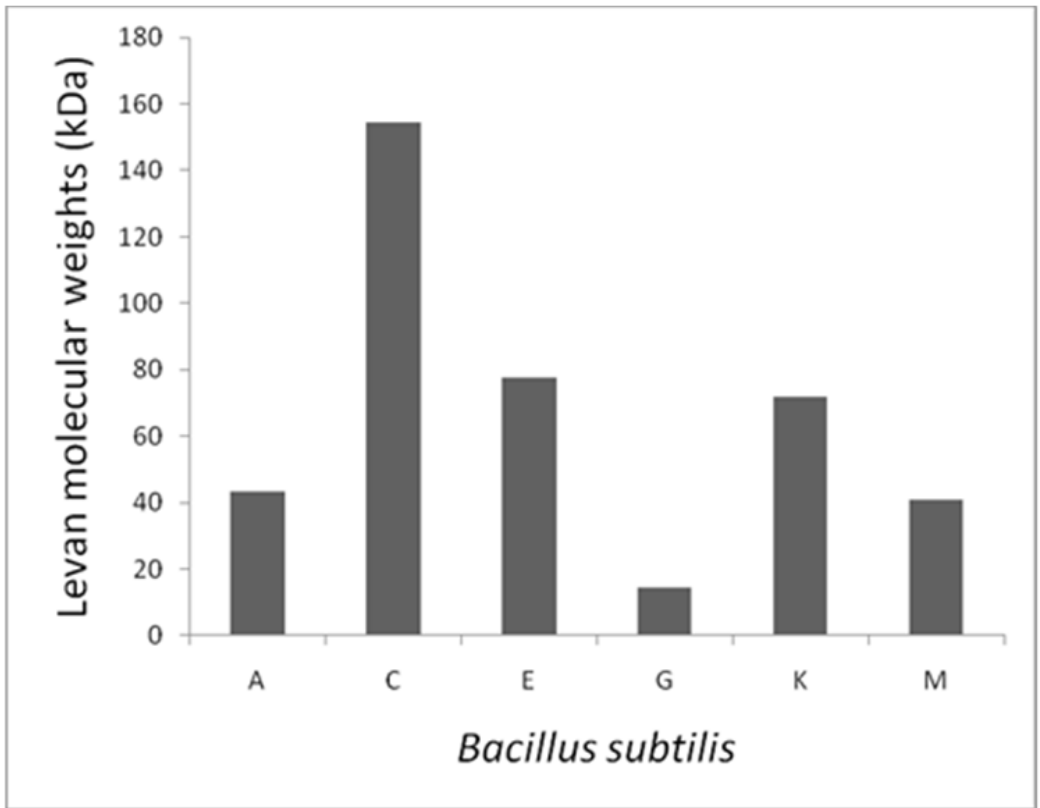

Figure 6. The levan molecular weights from Bacillus subtilis isolates 


\subsection{Cytotoxicity test}

The non toxic doses for samples C and G were $0.5 \mathrm{mg} / \mathrm{mL}$ in water. On the other hand, the non toxic doses for samples $\mathrm{A}, \mathrm{E}$, and $\mathrm{M}$ were $0.2 \mathrm{mg} / \mathrm{mL}$ in ethanol while the nontoxic dose of sample $\mathrm{K}$ was $0.1 \mathrm{mg} / \mathrm{ml}$ in ethanol.

\subsection{Anti-adenovirus type 40 assay}

The samples (C, E, G and K) had weak effect on adenovirus 40 which did not exceed $10 \%$. The two samples $\mathrm{A}$ and $\mathrm{M}$ revealed antiviral effect on adenovirus type 40 ranged from 50 to $60 \%$ as shown in Table 2.

\begin{tabular}{|c|c|c|c|}
\hline Sample & Initial viral doses & Final viral doses & Percentage of reduction \\
\hline \multirow{2}{*}{$\mathrm{A}$} & $1 \times 10^{4}$ & $4 \times 10^{3}$ & $60 \%$ \\
& $1 \times 10^{5}$ & $5 \times 10^{4}$ & $50 \%$ \\
& $1 \times 10^{6}$ & $5 \times 10^{5}$ & $50 \%$ \\
\cline { 2 - 3 } & $1 \times 10^{4}$ & $4 \times 10^{3}$ & $60 \%$ \\
\cline { 2 - 3 } $\mathrm{M}$ & $1 \times 10^{5}$ & $4 \times 10^{4}$ & $60 \%$ \\
& $1 \times 10^{6}$ & $5 \times 10^{5}$ & $50 \%$ \\
\cline { 2 - 3 } & & & \\
\cline { 2 - 3 } & &
\end{tabular}

Table 2. Effect of levan A and levan $\mathrm{M}$ on the infectivity of enteric adenovirus type 40 (DNA virus). viral infectivity.

\subsection{Anti-H5N1 virus assay}

All the embryos of the positive controls died and the allantoic fluid of each was positive for haemagglutination assay (HA), while all the embryo of negative control were not died and the allantoic fluid of each was negative for HA. Three levans of code K, M, E showed antiviral against HPAI H5N1. Each of these samples showed antiviral effect when inoculated with $\mathrm{H} 5 \mathrm{~N} 1$ virus $1 \mathrm{~h}$ before inoculation into nine days old ECEs, while they had no effect on the virus when inoculated simultaneously with the virus just after mixing or after the virus inoculation for $1 \mathrm{~h}$ (Table 3). These results also revealed that simultaneous inoculation of the levans product or even after infection was of no value.

\begin{tabular}{|c|c|c|c|c|c|c|c|c|c|c|}
\hline \multirow{3}{*}{$\begin{array}{l}\text { Code of } \\
\text { sample }\end{array}$} & \multicolumn{6}{|c|}{ Experiment 1} & \multicolumn{2}{|c|}{ Experiment 2} & \multicolumn{2}{|c|}{ Experiment 3} \\
\hline & \multicolumn{2}{|c|}{ Level 1} & \multicolumn{2}{|c|}{ Level 2} & \multicolumn{2}{|c|}{ Level 3} & \multirow{2}{*}{ NDE } & \multirow{2}{*}{$+\mathrm{HA}$} & \multirow{2}{*}{ NDE } & \multirow{2}{*}{$+\mathrm{HA}$} \\
\hline & NDE & $+\mathrm{HA}$ & NDE & $+\mathrm{HA}$ & NDE & $+\mathrm{HA}$ & & & & \\
\hline con & $5 / 5$ & 5.0 & $5 / 5$ & 5.0 & $5 / 5$ & 5.0 & $5 / 5$ & 5.0 & $5 / 5$ & 5.0 \\
\hline $\mathrm{M}$ & $0 / 5$ & 0.0 & $5 / 5$ & 5.0 & $5 / 5$ & 5.0 & $5 / 5$ & 5.0 & $5 / 5$ & 5.0 \\
\hline $\mathrm{C}$ & $5 / 5$ & 5.0 & $5 / 5$ & 5.0 & $5 / 5$ & 5.0 & $5 / 5$ & 5.0 & $5 / 5$ & 5.0 \\
\hline$E$ & $0 / 5$ & 0.0 & $5 / 5$ & 5.0 & $5 / 5$ & 5.0 & $5 / 5$ & 5.0 & $5 / 5$ & 5.0 \\
\hline $\mathrm{K}$ & $0 / 5$ & 0.0 & $5 / 5$ & 5.0 & $5 / 5$ & 5.0 & $5 / 5$ & 5.0 & $5 / 5$ & 5.0 \\
\hline
\end{tabular}

Table 3. Showed that three levans of code K, M, E had antiviral against HPAI- H5N1 NDE: Number dead Haemagglutination assay 


\section{Discussion}

The public health and the discovery of new drugs is a main objective of many research activities, however, sometime this type of research activity cost a lot of money. Although, in this proposed research we will be aiming towards the protection of the public health and introduce a new drugs contribute in solve the problem of serious diseases through products that will save a lot of money to our economy. Within this context, six mobile spore-forming, and Gram-positive facultative aerobic bacilli were isolated from different honey samples and identified as Bacillus spp. On the base of morphological, and molecular identification, using $16 \mathrm{~S}$ rRNA sequence method. B. subtilis isolates are biologically and commercially important as producers of a great variety of secondary metabolites such as antibiotics, and enzymes (Desai \& Banat 1997; Roberts et al., 1996). The16S rRNA sequence method could not identify the Bacillus isolates at the species level where revealed identical to any of three strains B. subtilis or B. licheniformis or B. amyloliquefaciens. In fact DNA-based identification methods such as $16 \mathrm{~S}$ rRNA gene sequencing and 16S-23S intergenic region sequencing have been used widely for the purpose of identification and typing of microorganisms isolated from natural environments including fermented foods (Hansen et al., 2001; Levine, et al., 2005). But identification based on rRNA gene sequences fails to distinguish one species from the other if they share highly similar rRNA genes. This is true for some Bacillus species. It is difficult to distinguish B. subtilis from closely related B. licheniformis or B. amyloliquefaciens by rRNA gene sequences because of no significant differences in their rRNA sequences (Nakamura, 1989; Nakamura et al., 1999). Other genes such as recA (Rodriguez et al., 2007) and dnaJ (Shah et al., 2007) have been employed instead of rRNA genes. It is necessary to compare results from different identification methods as a whole before to reach a conclusion (Bourque et al., 1995).

To solve the ambiguity in differentiating them based solely on the 16S rRNA gene, it was turned to $16-23 S$ intergenic region, recA gene, and ended with $B$. subtilis specific primers. It is specifically useful to distinguish organisms with highly similar rRNA genes recA gene was amplified from the chromosomal DNA of bacilli isolates by PCR, using primers (recF and recR) (Payne et al., 2005). When rRNA and recA gene sequences were considered together, it was possible to conclude that the $G$, $M$ isolates are belonging to $B$. subtilis but the other isolates A, C, E needed further identification. For the accurate distinguish between the 6 isolates, the specific-PCR for B. subtilis based on ytcP gene was used and the results revealed that the six strains are belonging to $B$. subtilis. The present results proved high phenotypic and genotypic variability among B. subtilis isolates, where they showed different morphological and biological properties suggesting them as new different species of $B$. subtilis with valuable impact in the industry. Many authors reported in the production of levansucrase from B. subtilis (Euzenat et al., 1997; Le Gorrec et al., 2002). The various sugars, initial $\mathrm{pH}$, fermentation temperature, and agitation speed affected the levansucrase production by B. subtilis (Abdel-Fattah et al., 2005; Shih et al., 2005). The result ensure the halophilc feature of $B$. subtilis levansucrases, this comes from its osmophilic character. Enhancements of levansucrase production in the presence of $\mathrm{NaCl}$ were reported (Euzenat et al., 2006; Poli et al., 2009). As far as we are aware no studies were reported on the effect of $\mathrm{NaCl}$ on the enzyme production. It seemed that levan production by the isolates was 
dependent mainly on commercial sucrose media, where the use of beet molasses, glucose, and lactose led to noticeable reduction in levan synthesis. Beet molasses was used as lowcost substitutes for sucrose in commercial levan yield (Han \& Watson, 1992). The decrease in levan yield in the molasses medium $(2.533 \mathrm{~g} / \mathrm{L})$ when compared to the commercial sucrose (21.685 g/L) was also reported (De Oliveira et al., 2007). Although higher Halomonas sp. AAD6 biomass concentrations were observed when glucose, maltose, fructose and galactose were used as carbon sources, levan levels were very low comparing with sucrose (Poli et al., 2009). The six isolates produced different levan weights, with wide range of molecular mass. On the other hand, it was reported that halophilic Halomonas sp. AAD6 cells grown in the presence of sucrose afforded the highest levan production levels $(1.073 \mathrm{~g} / \mathrm{L})$ (Poli et al., 2009). Also, B. polymyxa produced about $40 \mathrm{~g} / \mathrm{L}$ extracellular polysaccharide per liter in sucrose medium, which was about three times that produced by familiar levan producers (Han, 1989). Levan antitumor activity was reported by many authors (Yoon, Yoo, Cha, \& Lee, 2004,) but as far as we are aware nothing was reported on antiviral activity of this fructose polymer. The present findings showed antiviral effects of $K, M$, and $E$ levan products on $\mathrm{H} 5 \mathrm{~N} 1$ virus, While, $\mathrm{A}$ and $\mathrm{M}$ levan products showed antiviral effects on adenovirus type-40. It was obvious that the product $\mathrm{M}$ was entirely effective against both respiratory RNA virus (H5N1) and enteric adenovirus type 40 (DNA virus). It was apparent that each of effective levan showed antiviral effect when inoculated with H5N1 virus $1 \mathrm{~h}$ before inoculation into nine days old ECEs, while they had no effect on the virus when inoculated simultaneously with the virus just after mixing or after $1 \mathrm{~h}$ of inoculation.

The outcome of this study is the probable suitability of some types of levan as a safe and cheap natural product in antiviral treatments with applying the known roles concerning the use of these compounds. In addition, this article affords honey micro flora as a new and important sources of levansucrase enzymes, could be have biotechnological applications in pharmaceutical industries.

\section{Author details}

Mona A. Esawy*, Eman F. Ahmed and Wafaa A. Helmy

Department of Chemistry of Natural and Microbial Products,

National Research Centre, Dokki, Giza, Egypt

Nahla M. Mansour

Gut Microbiology and Immunology Lab,

Central of Excellence for Advanced Sciences (CEAS), National Research Centre, Dokki, Giza, Egypt

Waled M. El-Senousy

Water Pollution Research Department, National Research Centre, Dokki, Giza, Egypt

Mounir M. El-Safty

Central Laboratory for Evaluation of Veterinary Biologics (CLVB), Abbassia, Cairo, Egypt

\footnotetext{
${ }^{*}$ Corresponding Author
} 


\section{References}

Abdel-Fattah, A. F., Mahmoud, D. A. R., \& Esawy, M. A. (2005). Production of levansucrase from Bacillus subtilis NRC 33a and enzymic synthesis of levan and fructooligosaccharides. Current Microbiology, 51, 402-407.

Abdel-Fattah, A.M., Gamal-Eldeen, A.M., Helmy, W.A., \& Esawy, M.A. Antitumor and antioxidant activities of levan and its derivative from the isolate Bacillus subtilis NRC1aza. Carbohydrate Polymers xx (2012)89, 314-322

Ash, C., Farrow, J. A. E., Dorsch, M. E., Stackebrandt, E., \& Collins, M. D. (1991). Comparative analysis of Bacillus anthracis, Bacillus cereus and related species on the basis of reverse transcriptase sequencing of $16 \mathrm{~S}$ rRNA. International Journal of Systemic Bacteriology, 141, 343-346.

Arvidson, S.A., Rinehart, B.T., \& Gadala-Maria F. (2006). Concentration regimes of solutions of levan polysaccharide from Bacillus sp. Carbohydrate Polymers 65 144-149.

Baird $^{1}$, P. A. Sandford ${ }^{1}$ \& I. W. Cottrell. Industrial Applications of Some New Microbial Polysaccharides Nature Biotechnology 1, 778 - 783 (1983)

Barone, J.R., \& Medynets, M., Thermally processed levan polymers, Carbohydrate Polymers 69 (2007) 554-561

Beine, R., Moraru, R., Nimtz, M., Na'amnieh, S., Pawlowski, A., \& Buchholz, K. (2008). Synthesis of novel fructooligosaccharides by substrate and enzyme engineering. Journal of Biotechnology, 138, 33-41.

Ben Ammar, B. Y., Matsubara, T., Ito, K., Iizuka, M., Limpaseni, T., \& Pongsawasdi, P., et al. (2002). Characterization of a thermostable levansucrase from Bacillus sp. TH4-2 capable of producing high molecular weight levan at high temperature. Journal of Biotechnology, 99, 111-119.

Block, R. J., Durrum, E. L., \& Zweig, G. (1995). A manual of paper chromatography and paper electrophoresis. New York, NY: Academic Press Inc., pp. 127

Bourque, S. N., Valero, J. R., Lavoie, M. C., \& Levesque, R. C. (1995). Comparative analysis of the 16 to $23 \mathrm{~S}$ ribosomal intergenic spacer region sequences of Bacillus thuringiensis strains and subspecies and of closely related species. Applied Microbiology and Biotechnology, 61, 1623-1626.

Crosby, Alfred W. (2004). Ecological Imperialism: The Biological Expansion of Europe, 9001900. Cambridge University Press, 188. ISBN 0-521-54618- 4. "There are many kinds of bees and other insects producing honey all round the world"

Dahech I, Belghith, K.S, Hamden, K, Feki, A., Belghith H, \& Mejdoub, H. (2011). Antidiabetic activity of levan polysaccharide in alloxan-induced diabetic rats. International Journal of Biological Macromolecules. 2011 49:742-6.

De Oliveira, M. R., Da Silva, R. S. S. F., Buzato, J. B., \& Celligoi, M. A. P. C. (2007, November). Study of levan production by Zymomonas mobilis using regional low-cost carbohydrate sources. Biochemical Engineering Journal, 37: 177-183.

Desai, J. D., \& Banat, I. M. (1997). Microbial production of surfactant and their commercial potential. Microbiology and Molecular Biology Review, 61, 47-64. 
EsawyI, M. A.; MahmoudI; D. A. R. \& Abd- Fattah A. F. (2008). Immobilisation of Bacillus subtilis NRC33a levansucrase and some studies on its properties. Brazilian Journal of Chemical Engineering 25: 237-246

Esawy, M.A., Ahmed, E.F., Helmy, W. A., Mansour, N.M., El-Senousy,W.M., \& El-Safty , M.M. (2011). Production of levansucrase from novel honey Bacillus subtilis isolates capable of producing antiviral levans. Carbohydrate Polymer, 36, 823-830

Esawya, M. A.; Mansour, S. H; Ahmed, E. F., Hassanein, N.M. \& El Enshasy, H.A. (2012). Characterization of Extracellular Dextranase from a Novel Halophilic Bacillus subtilis NRC-B233b a Mutagenic Honey Isolate under Solid State Fermentation E-Journal of Chemistry 9: 1494-1510

Esawyb, M.A.; Awad G.E.A., Mansour, S. H; Ahmed, E. F., \& Danial, E.N. Evaluation of honey as new reservoir for probiotic bacteria. Advances in food science. V: 43 (2) in press.

Euzenat, O., Guibert, A., \& Combes, D. (1997). Production of fructo-oligosaccharides by levansucrase from Bacillus subtilis C4. Process Biochemistry, 32, 237-243.

Euzenat, O., Guibert, A., \& Combes, D. (2006). Production and purification of Bacillus subtilis C4 levansucrase kinetic characterization of the enzyme. Annals of the New York Academy of Sciences, 864, 288-294.

Han, Y. W. (1989). Levan production by Bacillus polymyxa. Journal of Industrial Microbiology, 4, 447-452.

Han, Y. W., \& Watson, M. A. (1992). Production of microbial levan from sucrose, sugarcane juice and beet molasses. Journal of Industrial Microbiology, 9, 257-260.

Hansen, B. M, Leser, T. D., \& Hendriksen, N. B. (2001). Polymerase chain reaction assay for the detection of Bacillus cereus group cells. FEMS Microbiology Letters, 202, 209-213.

Hernandez, L., Arrieta, J., Menendez, C., Vazquez, R., Coego, A., Suarez, V., et al. (1995). Isolation and enzymatic properties of levansucrase secreted by Acetobacter diazotrophicus SRT4, a bacterium associated with sugar cane. Biochemistry journal, 309, 113-118.

Hettwer, U., Gross, M., and Rudolph, K., (1995): Purification and characterization of an extracellular levansucrase from Pseudomonas syringae pv Phaseolicola. Journal of Bacteriology, pp. 2834-2839.

Huber, A. E., Stayton, P. S., Viney, C., \& Kaplan, D. L. (1994). Liquid crystallinity of a biological polysaccharide: the levan/water phase diagram. Macromolecules, 27, 953957.

Kang, (2009): "Levan: Applications and Perspectives". Microbial Production of Biopolymers and Polymer Precursors. Caister Academic Press. ISBN 978-1-904455-36-3.

Kasapis, S. \& Morris, E., (1994) Conformation and physical properties of two unusual microbial polysaccharides: Rhizobium trifolii CPS and Levan. In Food Hydrocolloids: Structures, Properties and Functions, ed by K. Nishinari, Plenum Press, New York, pp 97-103. 
Kasapis, S., Morris, E., Gross, M., \& Rudolph, K., (1994): Solution properties of levan polysaccharide from Pseudomonas syringae pv. phaseolicola, and its possible primary role as a blocker of recognition during pathogenesis. Carbohydrate Polymers. 23: 55-64.

Keith, J., Wiley, B., Ball, D., Arcidiacono, S., Zorfass, D., Mayer, J., \& Kaplan, D. (1991): Continuous culture system for production of biopolymer levan using Erwinia herbicola. Biotechnology and Bioengineering, 38: 557-560.

Kojima, I., Saito, T., Iizuka, M., Minamiura, N., \& Ono, S. (1993). Characterization of levan produced by Serratia sp. Journal of Fermentation and Bioengineering, 75, 9-12.

Kwon, H. K., Lee, H. A., Park, J. Y., Kim, J. S., Lim, J., \& Park, C. S., et al. (2009). Development of a RAPD-PCR method for identification of Bacillus species isolated from Cheonggukjang. International Journal of Food Microbiology, 129, 282-287.

Le Gorrec, K., Connes, C., \& Guibert, A., et al. (2002). Identification of three inducible and extracellular enzymatic activities working on sucrose in Bacillus subtilis NCIMB 11871 and 11872 supernatant. Enzyme and Microbial Technology, 31, 44-52.

Levine, S. M., Tang, Y. W., \& Pei, Z. (2005). Recent advances in the rapid detection of Bacillus anthracis. Reviews in Medical Microbiology, 16, 125-133.

Lizuka, M., Tanaka, T., Yamamoto, S., et al. (1991). Synthesis of fructan and oligosaccharides by microbial and plant fructosyltransferases. Denpun Kagaku, 38, 217-222.

Liu, J., Luo, J., Ye, H., \& Zeng, X. (2012). Preparation, antioxidant and antitumor activities in vitro of different derivatives of levan from endophytic bacterium Paenibacillus polymyxa EJS-3. Food and Chemical Toxicology, 50, 767-772.

Madigan, M. T., \& Martinko, J. M. (2005). Brock Biology of Microorganisms (11th ed.). Pearson Prentice Hall.

Nakamura, L. K. (1989). Taxonomic relationship of black-pigmented Bacillus subtilis strains and a proposal for Bacillus atrophaeus sp. nov. International Journal of Systematic Bacteriology, 39, 295-300.

Nakamura, L. K., Roberts, M. S., \& Cohan, F. M. (1999). Relationship of Bacillus subtilis clades associated with strains 168 and W23: A proposal for Bacillus subtilis subsp. subtilis subsp. nov. and Bacillus subtilis subsp. spizizenii subsp. nov. International Journal of Systematic Bacteriology, 49, 1211-1215.

Newbrun, E., and Baker, S., (1968): Physico-chemical characteristics of the levan produced by Streptococcus salivarius. Carbohydrate Research, 6: 165-170.

O'Sullivan, D. J., \& Klaenhammer, T. R. (1993). Rapid mini-prep isolation of high quality plasmid DNA from Lactococcus and Lactobacillus spp. Applied and Environment Microbiology, 59, 2730-2733.

Payne, G. W., Vandamme, P., Morgan, S. H., et al. (2005). Development of a recA gene-based identification approach for the entire Burkholderia genus. Applied and Environmental Microbiology, 71, 3917-3927.

Poli, A., Kazak, H., \& Gürleyenda g, B., et al. (2009). High level synthesis of levan by a novel Halomonas species growing on defined media. Carbohydrate Polymers, 78, 651-657. 
Pontis, H. G., \& Del Campillo, E. (1985). Fructans. In M. Dey, \& R. A. Dixon (Eds.), Biochemistry of storage carbohydrates in green plants (pp. 205-277). Academic Press Inc.

Puig, M., Jofre, J., Lucena, F., Allard, A., Wadell, G., \& Girones, R. (1994). Detection of adenovirus and enterovirus in polluted waters by nested PCR amplification. Applied and Environmental Microbiology, 60, 2963-2970.

Roberts, M.S., Nakamura, L.K., \& Cohan, F.M. (1996). Bacillus vallismortis sp. nov., a close relative of Bacillus subtilis, isolated from soil in Death Valley, CA. Interational Journal of Systemic Bacteriology, 46, 470-475.

Rodriguez, H., de las Rivas, B., \& Muňoz, R. (2007). Efficacy of recA gene sequence analysis in the identification and discrimination of Lactobacillus hilgardii strains isolated from stuck wine fermentations. International Journal of Food Microbiology, 115:70-78

Root, A.L., The ABC and XYZ of bee culture. London: Edward Arnold publication Ltd.; 1993. pp. 5-28.

Rhee, S., Song, K., Kim, C., Park, B., Jang, E., \& Jang, K., (2002): Levan. In A.Steinbu“ chel (Ed.), Biopolymers; polysaccharides, pages 351-377.

Sabaté, D. C., Carrillo, L., \& Audisio, M. C. (2009). Inhibition of Paenibacillus honey samples. Research Microbiology, 160, 193-199.

Sambrook, J., Fritsch, E. F., \& Maniattis, T. (1989). Molecular cloning: A laboratory manual. Cold Spring Harbor, NY: Cold Spring Harbor Laboratory.

Sanders, M. E., Morelli, L., \& Tompkins, T. A. (2003). Sporeformers as human probiotics: Bacillus, Sporolactobacillus, and Brevibacillus. Comprehensive Reviews inFood Science and Food Safety (CRFSFS), 2, 101-110.

Shah, M. M., Lihara, H., Noda, M., Song, S. X., Nhung, P. H., \& Ghkusu, K., et al. (2007). dnaJ gene sequence-based assay for species identification and phylogene grouping in the genus Staphylococcus. International Journal of Systematic and Evolutionary Microbiology, 57, 25-30.

Shih, I., Shieh, Y., Yu, C., \& Hsieh, C. (2005). Selective production and characterization of levan by Bacillus subtilis (Natto) Takahashi. Journal of Agriculture Food Chemistry, 53, 8211-8215.

Simões, C., Amoros, M., \& Girre, L. (1999). Mechanism of antiviral activity of triterpenoid saponins. Phytotherapy Research, 21, 317-325.

Stivala, S., and Bahary, W., (1978): Some dilute-solution parameters of the levan of Streptococcus salivarius in various solvents. Carbohydrate Research. 67: 17-21

Takatsy, G. (1955). The use of spiral loops in serological and virological micromethods. Acta Microbiologica Academic Science Hungarica, 3, 191.

Urdaci, M. C., Bressollier, P., \& Pinchuk, I. (2004). Bacillus clausii antimicrobial and immunomodulatory activities. Journal of Clinical Gastroenterology, 38, 586-590.

Walum, E., Strenberg, K., \& Jenssen, D. (1990). Understanding cell toxicology: Principlesand practice. NewYork: Ellis Howood., pp. 97-111. 
Yanase, H., Iwata, M., Nakahigashi, R., Kita, K., Kato, N., \& Tonomura, K. (1992). Purification, crystallization, and properties of extracellular levansucrase from Zymomonas mobilis. Bioscience, Biotechnology and Biochemistry, 56, 1335-1337.

Yoo, S. H., Yoon, E. J., Cha, J., \& Lee, H. G. (2004). Antitumor activity of levan 536 polysaccharides from selected microorganisms. International Journal of Biological Macromolecules, 34, 37-41.

Yoon, E. J., Yoo, S. H., Cha, J., \& Lee, H. G. (2004). Effect of levan's branching structure on antitumor activity. International Journal of Biological Macromolecules, 34, 191-194. 